\title{
Voting on a social contract
}

$\mathrm{T}$ he proposition was simple and straightforward: If the Canadian Medical Association's vaunted transformation agenda was really about patient care, and not about money, then delegates to the CMA's 142 nd annual general meeting in Saskatoon, Saskatchewan, should censure extra billing.

The mover of the motion, Yellowknife, Northwest Territories, obstetrician Dr. Andrew Kotaska, was extraordinarily eloquent.

"Four decades ago, Canadians entered into the social contract with their physicians known as medicare," Kotaska said. "In exchange for a generous, recession-proof income, Canada's physicians have participated almost exclusively in our public health care system that prohibits extra billing. Many of the recent pioneers of private health care in Canada were motivated primarily by the needs of their patients for more timely care; however, in many private clinics, expedited care is now provided to patients willing and able to pay much higher than those in the public system."

"There are only two reasons for this fee differential. From the patient's perspective, paying more allows them to jump the queue. From the physician's perspective, charging more enhances income. Within the context of the social contract, neither of these are ethically justifiable."

"Witnessing these practices," Kotaska added, "the Canadian public rightly wonders whether our advocacy of patient-focused funding, internal market mechanisms and an increased role for private health care represent a desire to reaffirm or break their social contract with us."

In response, delegates voted for their pocketbooks, blowing Kotaska's motion out of the water by a decisive margin: $66 \%$ (172 votes) to 33\% (72 votes), with $1 \%$ (3 voters) abstaining.

Opponents offered a raft of arguments, generally related to the CMA

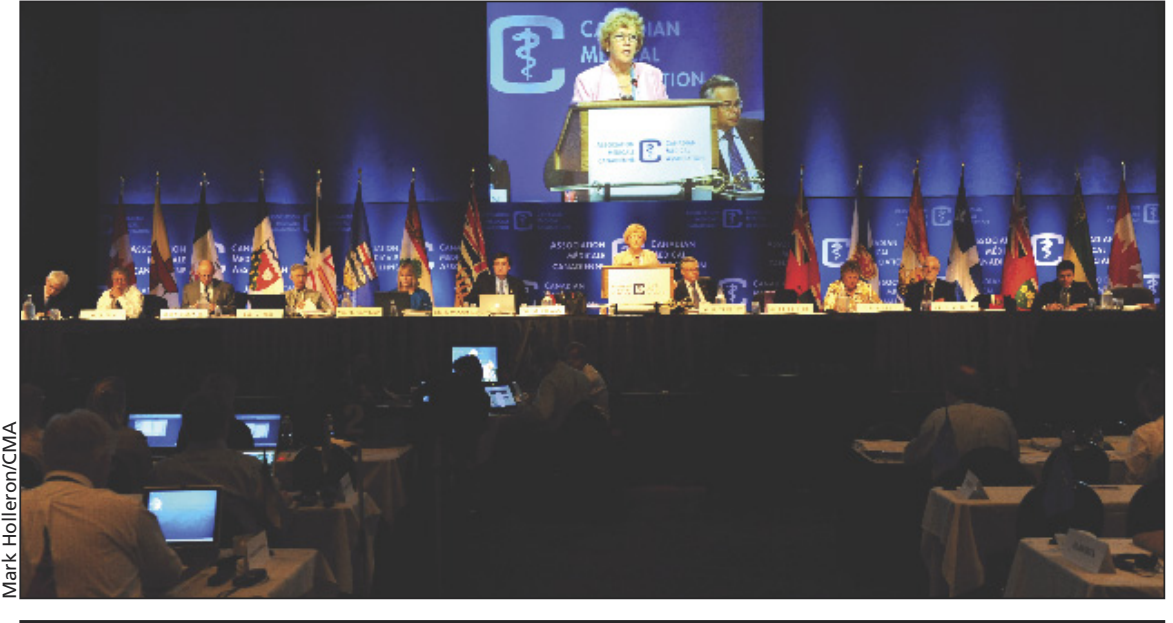

CMA delegates voted against censuring extra billing for private-sector services.

transformation agenda's proposition that the health care system should be made more market-driven.

A prohibition against earning more for a service in the private sector than for the same service in the public system is an intrusion on physician freedom, several argued.

"It doesn't allow for us to evolve in our system," said Alberta delegate Dr. Tzu-Kuang Lee. "This is an unnecessary shackle."

It's up to governments to curb extrabilling, not doctors, argued Richmond, British Columbia, delegate Dr. Victor Dirnfield.

"Physicians will have less opportunity to make a choice," said Summerside, Prince Edward Island, delegate Dr. Roland Chiasson.

With their vote, as with every resolution related to the CMA's planned move to develop a "transformation" blueprint to make health care more market-driven, the majority of delegates also reaffirmed what clearly has become widespread dissatisfaction with medicare.

As outgoing CMA President Dr. Robert Ouellet later told reporters, Canada's doctors are "fed up with the system because it's not working well."

Kotaska was disappointed. "I did think that this body represents the col- lective conscience of the medical profession in Canada and I think, within time, we're going to have to dig deeper into that conscience."

Among other transformation-related resolutions passed by delegates were ones obliging CMA to "carry out an inventory and assessment of the payment arrangements across Canada that foster the emergency of new practice models," and to conduct a study of "international experience and research related to pay for performance and quality measures in family medicine."

Delegates also approved CMA financial support for the New Brunswick Medical Association's court challenge to its provincial government's decision to unilaterally abrogate the terms of their collective bargaining agreement.

Other approved resolutions included one to press the federal government to appoint an independent expert panel to assess whether the discontinued MAPLE (Multipurpose Applied Physics Lattice Experiment) reactors have truly shot their bolt, another to essentially lobby for shutdown of chrysotile asbestos industry and a third urging a concerted lobby of the food industry to reduce salt content in processed food. - Wayne Kondro, CMAJ

DOI:10.1503/cmaj.109-3026 